\title{
The role of cilia and ciliary motility in otolith formation in the zebrafish embryo
}

\author{
G Stooke-Vaughan ${ }^{1 *}$, P Huang ${ }^{2}$, KL Hammond $^{1}$, AF Schier ${ }^{2}, \pi$ Whitfield ${ }^{1}$ \\ From First International Cilia in Development and Disease Scientific Conference (2012) \\ London, UK. 16-18 May 2012
}

Zebrafish otic vesicle (OV) luminal cells are monociliated from cavitation at 18.5 hours post fertilisation. Over the next 6 hours, otolith precursor particles are secreted into the $\mathrm{OV}$ and tether to the tips of the first forming hair cell kinocilia at the anterior and posterior poles of the OV, forming two otoliths (structures required for hearing and balance). Previous models of the mechanism of otolith tethering have recognised the importance of cilia for this process but disagreed on the number and distribution of motile and immotile cilia in the OV. Using high-speed video microscopy we have shown that the majority (9298\%) of OV cilia, including the kinocilia, are immotile. Motile cilia are concentrated at the poles of the OV near the forming otoliths, and a few motile cilia are present on the medial wall of the OV. Mutants with a reduced number of cilia (iguana) or ciliary motility defects ( $\operatorname{rrc} 50)$ often have abnormal otoliths. We have also shown that hair cells are required for otolith nucleation: if ectopic hair cells are formed (mindbomb mutant or $\mathrm{Su}(H)$ morphant), otolith precursor particles bind to all the kinocilia. If hair cells are absent (atoh1b morphant), otolith formation is delayed, and a single untethered otolith forms. Surprisingly, in the absence of cilia ( $M Z o v l$ mutant) otolith precursors can tether on the apical surface of hair cells, including ectopic hair cells formed in an $M Z o v l$ mutant injected with $\mathrm{Su}(H)$ morpholino. Embryonic movement also plays a minor role in normal otolith formation.

http://cdbg.shef.ac.uk/research/whitfield/

Author details

${ }^{1}$ University of Sheffield,UK. ${ }^{2}$ Harvard University, USA.

Published: 16 November 2012

* Correspondence: mdp09gas@sheffield.ac.uk

'University of Sheffield,UK

Full list of author information is available at the end of the article
doi:10.1186/2046-2530-1-S1-P78

Cite this article as: Stooke-Vaughan et al.: The role of cilia and ciliary motility in otolith formation in the zebrafish embryo. Cilia 2012 1(Suppl 1):P78.
Submit your next manuscript to BioMed Central and take full advantage of:

- Convenient online submission

- Thorough peer review

- No space constraints or color figure charges

- Immediate publication on acceptance

- Inclusion in PubMed, CAS, Scopus and Google Scholar

- Research which is freely available for redistribution
() Biomed Central
C Biomed Central

ㄷ 2012 Stooke-Vaughan et al; licensee BioMed Central Ltd. This is an Open Access article distributed under the terms of the Creative Commons Attribution License (http://creativecommons.org/licenses/by/2.0), which permits unrestricted use, distribution, and reproduction in any medium, provided the original work is properly cited. 